\title{
AUTHOR'S ABILITY IN THE FORMATION OF PROFESSIONAL CULTURE OF THE FUTURE TEACHER OF MUSIC ART
}

\author{
Tatiana Stratan-Artyshkova ${ }^{1}$, Lyudmyla Nikolenko ${ }^{2}$ \\ ${ }^{1}$ Doctor of Pedagogical Sciences, Professor, Professor of the Department of Music Art and Methodology of \\ Music Education of Central Ukrainian State Pedagogical University by Volodymyr Vynnychenko, \\ Kropyvnytskyi, Ukraine, e-mail: starart05@gmail.com,ORCID: https://orcid.org/0000-0001-5507-1832 \\ ${ }^{2}$ Postgraduate student at the Department of Pedagogy and educational management department of Central \\ Ukrainian State Pedagogical University by Volodymyr Vynnychenko, Kropyvnytskyi, Ukraine, e-mail: \\ nikolenkoludmila41@gmail.com, ORCID: https://orcid.org/0000-0002-4065-6050
}

\begin{abstract}
Nowadays accelerated pace of scientific and technological progress requires competent professionals in a high sense of this word, with a formed worldview, views, beliefs, imagination, thinking, able to reveal and realize their spiritual and creative potential in professional activities, that is with a high level of culture. The analysis of scientific works on the researched problem allowed to define the professional culture of the future teacher of music as a complex integrated professional personal quality, which characterizes the future specialist as highly educated, creatively competent, able to realize the importance of cultural values in spiritual and creative development of the personality, capable of self-creation, self-expression and selfrealization in professional activities and socio-cultural space. Art as a sphere of spiritual culture integrates the unique meanings of humanity, gives the lessons of humanity, penetrates into the most mysterious corners of the human soul, enriches the spiritual world of a man, forms personal qualities, causes the need and the ability to create. Therefore, the defining problem of artistic education, in particular, musical and pedagogical, is the formation of a professional culture of future teachers who can establish a humanistic style of communication, organize a joint search for values and norms of behavior, to spiritually and practically comprehend and transform humanistic functions of art directed at development creative personality, its value relation to the phenomena of culture, to oneself, to society as a whole.

In the formation of professional culture of the future teacher of music a special importance is the involvement of future teachers of music in creative and performing activities, the essence of which is to solve pedagogical problems through "composition", the art of their own creation, the ability of future teachers of music to authorship, to express their inimitable uniqueness in their own work. Authorial ability as a criterion for the formation of professional culture of future teachers of music is characterized by the ability of future professionals to reproduce the musical image in various forms of artistic thinking, provides the future teacher's ability to be the author of own life and professional activity.
\end{abstract} music art.

Keywords: culture, professional culture, spiritual culture, author's ability, future teacher of

JEL Classification: I24, I29

Formulas: 0; fig.: 0; tabl.: 0; bibl.: 11

Introduction. Contemporary artistic education is aimed at the formation and development of a coherent personality, one's spirituality, creative individuality, intellectual and emotional wealth. Particular attention is paid to the formation of the professional culture of the future teacher of musical disciplines, who by means of art influences the development of personal qualities of the student, his ability to adequately perceive the world around him, express his attitude towards him by means of art.

The purpose of contemporary artistic education is to prepare a future specialist as a carrier of high professional culture, competent, highly educated, creative, 
professionally mobile, able to adequately perceive and evaluate artistic phenomena, to think critically, to master the ability to independently search, which enable a teacher to carry out one's professional activities successfully.

The meaning and the basis of the professional training of future teachers of any specialty is spiritual culture, since the goal of modern higher education is a person in constant development, one's spiritual formation, harmonization of one's relations with oneself, and with other people, with the world $[1 ; 3]$.

O. Rudnytska emphasizes the prospects of humanization of education, which is associated with art, which is becoming an increasingly important factor in the field of pedagogical knowledge as a kind of regulatory instrument for influencing the formation of a person. This factor develops the spiritual culture of the individual, implements a dialogical approach in the pedagogical process, orientation towards creative focus of the future teacher [11].

Literature review. The concept of professional culture in the scientific circle was introduced by J. Isaev, who defined it as a way of creative self-realization of the teacher's personality in various types of pedagogical activity and communication aimed at the development, transfering and creation of pedagogical values and technologies [5]. The author dwells on it as a system formation, which combines structural and functional components, has its own integral organization, selectively interacts with the environment and has integral-integrative properties. We agree with the opinion of a scientist who considers the formation of professional culture in the unity of interacting structural and functional components. Considering professional culture as a system, J. Isaev emphasizes that this phenomenon is a system formation, which combines a number of structural and functional components, has its own organization, selectively interacts with the environment, and possesses integrative properties of the whole [5]. Therefore, according to researchers, professional culture is the professional quality of the subject of work, that is, the degree of mastering the specialist achievements of scientific and technological and social progress and is a personal aspect of the culture of labor. The main elements are qualifications and professional experience. Based on this definition, we will note the need for a professional culture of professional competences (knowledge, skills and abilities), without which the future specialist is not able to achieve creative self-realization in professional activity.

Actual problems of the formation of the professional culture of future specialists of art are highlighted in the scientific works of J. Kevishas, O. Oleksyuk, V. Orlov, G. Padalka, O. Rostovsky, O. Rudnitska and others. Scientists emphasize that the modern concept of preparing the future teacher of music art presupposes, first of all, the creation of conditions for the formation of one's culture, which is based on the high level of general and professional development of the individual (O. Rudnytska). Pedagogical institutions of higher education should produce not only «subjects teachers», experts of narrow specialization, but truly intelligent people with a humanitarian worldview, says O. Oleksyuk, educated, qualified teachers of music art, capable of performing the honorary role of the bearer of music culture, self-asserting and self-realization in professional activity and life-creativity. V. Orlov notes that the 
artistic and pedagogical work and its results are the highest manifestation of the professional culture of the future specialist [9].

Researchers emphasize that the professional activity of the teacher of music art, which is creative in its essence, implies the dialectical unity of creativity and artistic knowledge, the formation of musical-performing competence, professional mobility, the presence of future specialists in the field of arts, art knowledge, creative and performing competences. Authors name such as: the ability to understand the artistic image and adequately evaluate, analyze and reveal its essence, arrange an original musical composition, create an author's musical composition, artistic and creative project, expressly perform instrumental or vocal work, improvisation with the corresponding structural and genre-stylistic characteristics, engage in performing and teach others to present their own products. A specialist fullfills these tasks with a high level of artistic thinking, emotional and intellectual culture of perception, stage performance.

Aims. To determine the essence and content of the concept «professional culture of the future teacher of music art»; to reveal the significance of the author's program in the formation of the professional culture of the future teacher of music.

Methods. It is known that the profession of the teacher of music is inherently creative and is based on the dialectical interaction of artistic cognition and pedagogical creativity. The teacher of music must think like a teacher and feel like an artist. The development and formation of a spiritual and creative personality, which is productive of life and creativity is the overring task, because creativity is the spiritual peak, life value, the highest social expression of human, the sphere of true freedom and freedom as an individual, an indicator of professional culture of future teachers.

Thus, the Ukrainian philosopher S. Krymsky defines spirituality as the ability to transform the universe of external existence into the inner universe of the individual on an ethical basis, the ability to create the inner world through which the selfidentity of a person is realized, and one's freedom from strong dependence on constantly changing situations. And spirituality itself is the way of self-building of the individual, because it is associated with the choice of one's own image, one's destiny and role, in short, a meeting with oneselves [7].

Spirituality as a category of human being, which expresses the ability of the individual to self-creation and the creation of culture, as the highest level of development of the individual, capable not only to know and reflect the world, but also to create it. R. Okhrimchuk notes that the result of creation is culture. Culture is a universal characteristic of human existence. «Entering» oneself into culture, (assimilating and creating it), a person joins the human dimension of being and remains in it in the process of life self-realization [4].

Spirituality involves the need for emotional and spiritual contact with people, the need for self-esteem and empathy for people, manifested in humanity, the desire to help another, the emergence of trust, empathy and tolerance.

Well-known teachers of musical art determine the essence of the spiritual culture of the individual as a component of the professional culture of the future specialist. Spirituality is an intrinsic quality of a man, which embodies the active 
desire to find the highest sense of his existence, to correlate his life with absolute values, and thereby engage in the spiritual universe of universal culture [8]; the system of vital senses of a person, connected with one's internal mental life and is directed on realization of humanistic values in activity [10].

G. Padalka defines the spiritual culture of the teacher of artistic disciplines as a person-professional formation, the essence of which is the ability to comprehend and create art from the standpoint of humanism, as well as the spread of this approach in the student environment [10], thus, emphasizing the importance of creativity as essentially-content component of the training of future teachers of musical art, the assimilation of the values of mankind as universal in the development of the spiritual culture of a personality.

Musical activity, observes O. Oleksyuk, becomes spiritual in the conditions of reaching the level of high morality, aesthetic perfection, truth and freedom of creativity [8]. In this way, the significance of creative expression as an important component of the professional culture of the future teacher of music art is determined, in which one's spiritual potential is the source of creative self-realization in perception, performance and creation.

Professional activity will be effective and efficient if the future specialist is a master of his business, an expert, a professional, who masters the basics of his profession, and possesses profound knowledge, professional competences that are necessary for self-realization in the further professional activity.

A modern professional is one who thinks creatively and critically, who is capable of solving problems individually and unordinary, who is responsible to them, and can teach beauty one's pupils, to reveal their internal qualities and creative potential.

Proceeding from the theoretical analysis of the above-mentioned works, we will define the professional culture of the future teacher of musical disciplines as a complex integrative entity that characterizes the personality of the future specialist and consists of value-motivational, creative-activity, evaluative-reflexive components.

In the formation of professional culture of special importance is the creative and performing activities of future teachers of music, which involves the ability to think as a composer, to embody the inner, subjective experience in the appropriate musical form, to have the laws of musical language, to understand expressive and formative functions, to know metro-rhythmic, intonation-texture, structural stereotypes of musical works of different styles; convert existing musical images in memory, create new ones on this basis. In addition, it is necessary to have properties that qualitatively characterize the composition and performance creative, that is the ability to empathize, fantasize, imagine, identify, to think associative-figurative and reflexiveintuitive and more.

Experimental work was carried out during the study of the course «Fundamentals of Composer's Skills», involved the use of creative approaches, aimed at stimulating the needs of future teachers for creative self-expression, mastering compositional and improvisational techniques, individual style of creative 
self-expression. As a result of this activity, future teachers mastered the stage and performance culture, improved the technique of artistic and pedagogical communication, acquired artistic skills, stage freedom, volitional qualities as indicators of the formation of professional culture.

Experimental work on the formation of authorial ability as a criterion for the formation of professional culture of future teachers of music made it possible to analyze the formation of students' attitude to their own creativity, desire to implement it, the ability to solve original and non-standard creative tasks, create their own original artistic and interpretive versions of musical works, creative projects.

Results. As a result of the student's involvement in composition and performance, his own musical work becomes an open figurative model of entering the world around him, as a result of which the spiritual and energetic potential increases and the spiritual and reflexive creativity of the individual becomes more active. Gaining experience of artistic perception-interpretation-creation, future teachers demonstrate the ability to express their own musical thoughts and feelings, embody them in artistic content and form, give them originality, individuality, demonstrate their own worldview concept, culture of artistic perception and performance, style artistic thinking, the ability to self-disclosure in their own individually created unique musical images.

The result of the realization of the artistic image (as a process), the author's creative talent embodies the peculiarities of his worldview as an artistic worldview, and the basis of the artistic worldview, the author's «image of reality» is the spiritual sphere of personality. Thus, it can be argued that his own work, musical composition, artistic and creative project indicates the development of spirituality, the level of emotional culture, artistic and figurative thinking, personal qualities of the author (student).

Discussion. Revealing the pedagogical aspect of «composition», we emphasize the differences in the preparation of the composer in the composition departments of conservatories (music academies), which train professional composers and the formation of the composer's personality in the music departments of art and music pedagogical faculties. individual-personal, creative-performing and pedagogical directions and is aimed at music education of the younger generation, which in turn allows to characterize the future teacher of music art as a holistic personality, independent, proactive, mobile, inventive, creative, competent, capable of adequate interpretation, own creation in various genres, styles and forms; (songs for children, individual musical works, musical and theatrical performances, musicals, creative projects, entertainment events), who has the teaching methods, attracts and teaches his own creation of students of other courses and other art specialties (future teachers of choreography and fine arts), establishes creative dialogue with the audience, shows responsibility and initiative in creative and executive activity in other educational institutions, applies and invents own technique of creative and executive activity, encourages creativity of the pupils. Therefore, the purpose of «composition» as an integrative definition would be not only to teach students to create their own works in a particular discipline, but to direct this activity to the future profession - a music 
teacher, as well as the possibility of self-development, self-expression and selfrealization in other fields of socio-cultural environment (gymnasiums, colleges, music schools, children's youth centers, art schools, theater, philharmonic, etc.).

Conclusion. Due to the specifics of musical and pedagogical activity, artistic values, national traditions, professional culture is an integral part of the general culture of the future specialist. The formation of the professional culture of the future teacher of musical disciplines would be based on human and artistic values, national traditions, experience, traditions, peculiarities of the development of musical culture of various artistic and historical epochs.

The purpose of musical and pedagogical education is the development of personality characterized by creative individuality, high level of social maturity, education, culture of thinking and feelings, practical knowledge, understanding of the essence of art, society and a human and one's interrelation in the development process, awareness of moral, aesthetic, spiritual values that form the purpose of one's existence.

The professional training of the future teacher of musical disciplines in the university would fulfill these tasks and functions, involve the future specialist in higher forms of compatibility and interaction, create the appropriate pedagogical conditions for the formation of professional culture of the future specialist.

In our study, the concept of «authorial ability» acquires a broader meaning than «composition», and is not limited to the process of own creation, composition, and embodying them, goes beyond learning and developing composition skills within a particular subject. The essence of the concept of «author's ability» is manifested in the ability of future professionals to carry out integrated interpretive and pedagogical activities: to perceive-interpret-create, express their individuality, self-affirmation and self-expression in art, as one of the most effective means of expanding opportunities for personal development himself, the discovery of a harmonious combination of special qualities on which the spiritual life is based.

Author contributions. The authors contributed equally.

Disclosure statement. The authors do not have any conflict of interest.

References:

1. Bekh I. D. (2012), Osobystist' u prostori dukhovnoho rozvytku : navchal'nyy posibnyk [Personality in the space of spiritual development: a textbook], Kyiv: Akademvydav [in Ukrainian].

2. Honcharenko S. U. (1997), Ukrayins'kyy pedahohichnyy slovnyk [Ukrainian pedagogical dictionary ], Kyiv: Lybid [in Ukrainian].

3. Zyazyun I. A. (2008), Filosofiya pedahohichnoyi diyi: monohrafiya [ Philosophy of pedagogical action: monograph ], Cherkasy : Vyd. vid CHNU imeni Bohdana Khmel'nyts'koho [in Ukrainian].

4. Entsyklopediya osvity (2008) / Akad. ped. nauk Ukrayiny; holovnyy red. V. I. Kremen' [Encyclopedia of Education / Acad. ped. Sciences of Ukraine; editor in chief V. I. Kremen], Kyiv : Yurinkom Inter [in Ukrainian].

5. Ysaev Y. F. (1993), Teoriya i praktika formirovaniya professional'no-pedagogicheskoy kul'tury prepodavatelya vysshey shkoly: [ucheb.posob.] [Theory and practice of the formation of professional and pedagogical culture of a teacher of higher education: textbook]. [in Russian].

6. Kevishas I. (2008), Stanovlennya muzychnoyi kul'tury shkolyara [Formation of musical culture of a schoolboy], Kirovohrad [in Ukrainian]

7. Krymskiy S. B. (1992), Kontury dukhovnosti : novyye konteksty identifikatsii [Contours of spirituality: new contexts of identification], Voprosy filosofii, 12, 21 - 28 [in Russian].

8. Oleksiuk O. M. (2004), Pedahohika dukhovnoho potentsialu osobystosti [Pedagogy of the spiritual potential of the individual], Kyiv: Znannia Ukrainy [in Ukrainian].

9. Orlov V. F. (2012), Pedahohichna maysternist' vykladacha mystets'kykh dystsyplin [Pedagogical skill of a teacher of art disciplines], Kyiv: Edelveis [in Ukrainian]. 
10. Padalka H. M. (2008), Pedahohika mystetstva : teoriya i metodyka mystets'kykh dystsyplin: navch. posib. [Pedagogy of art: theory and methods of artistic disciplines:textbook. aid.], Kyiv: Osvita Ukrainy [in Ukrainian].

11. Rudnytska O. P. (2005), Pedahohika zahal'na ta mystets'ka : navch. posib. [Pedagogy general and art: textbook. way.],Ternopil: Navchalna knyga - Bogdan [in Ukrainian]. 